\title{
Assessment of implementation and functioning of the ecological management system
}

\author{
Angela Mottaeva ${ }^{1, *}$ Andrey Ivashchenko ${ }^{2}$, and Alexandra Ryattel $^{3}$ \\ ${ }^{1}$ Moscow Region State University, 10A, Radio str, 105005, Moscow, Russia \\ ${ }^{2}$ Moscow State University of Civil Engineering, 26 Yaroslavskoye Shosse, Moscow, 109377, Russia \\ ${ }^{3}$ Vyatka State University, Moskovskaya str., 36, Kirov, 610000, Russia
}

\begin{abstract}
The relevance of the presented research is determined by the absence of any generally accepted methodology for assessing the economic results of the implementation of ecological management at the Russian enterprises. The introduction of the environmental management system at the enterprises is due to the demand of the world market, which main prerequisites are the tightening of requirements for goods, caused by the globalization processes by foreign consumers. The authors have defined the types of effects obtained by the industrial enterprise as the result of the implementation of the environmental management system. Three main types of effects were analyzed: social, economic, ecological. The research assessed the existing methods of calculating the economic efficiency of environmental measures and determined the possibility of their application for calculating the economic efficiency of the implementation of the environmental management system at the industrial enterprise. The author 's hypothesis on the existence of an image component of the economic effect in the implementation of the environmental management system at the enterprise is proposed. Prerequisites for implementation of environmental management are considered and comparative analysis of environmental management and environmental control is carried out. The model of the system of implementation and confirmation of environmental management is proposed.
\end{abstract}

\section{Introduction}

The concept of sustainable economic development adopted by the world community more than 20 years ago implies the combination of economic growth and environmental preservation.

Direct policy action without economic methods, is not an effective management tool. In the 1990s that led to the emergence of the environmental management concept, which allows to ensure direct impact of the responsibility for the quality environment and balanced growth of economic results and reduce negative impact on the environment. The introduction of the Environmental Management System (EMS) at Russian enterprises lags

\footnotetext{
* Corresponding author: angela-1309.m@yandex.ru
} 
far behind the world practice. SAM is a voluntary policy that is not limited to obtaining a certificate.

In Russia, the environmental management system is introduced by the enterprises operating on the world market in order to obtain a certificate, which is due to the requirements of consumers and the legislation of importing countries.

Economic entities themselves have no interest in introducing any environmental management system.

One of the reasons that makes it difficult to implement environmental management in Russian industrial enterprises is the absence of a generally accepted methodology for assessing the economic results of its implementation. The existing methods take into account either the reduction of penalties or the reduction of prevented damage, but that does not prove the real economic results of the implementation of the environmental management system at the enterprise.

Problems of preservation and improvement of the environmental situation, issues of assessment of economic results in carrying out environmental and resource-saving measures and prevented damage were considered by the following scientists: Anufriev V.P., Belik I.S., Vernadsky V.I., Golub A.A., Davankov A.Y., Danilov-Danillyan V.I., Ignatiev M., Issues of economic efficiency from the introduction and functioning of the environmental management system at industrial enterprises were considered in the works by Greenin A.S., Daiman S.Y., Elkina L.G., Ignatieva M.N., Carpovich A.P., Reimers N.F., Richter K.K., Endres A., etc.

However, despite the considerable amount of research, the matters of determining economic efficiency for entrepreneurs from the implementation of the environmental management system remain relevant. The need to show the dependence of the economic results to the management of the enterprise of the industrial enterprise on the implementation of the environmental management system and defined the goals and objectives of the study.

The purpose of this work is to develop a methodological approach to the comprehensive assessment of the economic results of the enterprise when implementing an environmental management system.

The environmental-and-economic aspect of governance has become relatively recent. Ecology and economics are interconnected. The depletion of natural resources, the deterioration of environmental quality and the impending environmental crisis are becoming a prerequisite for economic actors to meet pressing challenges, which are expressed in the harmonization of economic development and economic activities with environmental requirements and restrictions. Because of the deterioration in the quality of the natural environment, international cooperation is increasingly important for the rational use of natural resources and the environmental safety of the planet. Since the mid-20th century, the rapid development of the world economy has had a severe negative impact on the natural environment. As a result, humanity has faced the challenge of the growing needs of the world 's population and the inability of the biosphere to meet those needs.

The concept of sustainable development was adopted in Rio de Janeiro in 1992, and was recommended by the United Nations Conference on the Environment.

Sustainable development involves the gradual restoration of disturbed natural ecosystems. Economic development must be consistent with the principles of sustainable development.

Many international organizations, such as the International Union for Conservation of Nature (IUCN), the International Atomic Energy Agency (IAEA), the International Maritime Organization (IMO), the World Meteorological Organization of the United Nations (WMO), the United Nations Educational, Scientific and Cultural Commission (UNESCO), the World Health Organization (WHO), and others, are addressing. 
Russia takes its active part in the international agreements and conventions, which form the legal basis of international cooperation. Two areas of priority in the legal framework were the prevention and limitation of harmful impacts on the environment and the rational use of natural resources.

Environmental management was first discussed in Western countries in the second half of the 20th century. The worsening environmental situation in developed countries was the impetus for active environmental activity and the introduction of fundamentally different systems of enterprise management, which was to ensure the competitiveness of products, financial stability of the enterprise and a sufficient level of environmental safety in the market economy $[1,2,3,4]$.

At the moment in Russia, there is environmental management in all the enterprises, but the experience has proved that such management is most often limited to the compliance with legislative norms. Environmental management is introduced by the enterprises supplying products to the developed countries' markets [5].

The differences between environmental management and environmental control are presented in Table $1[6,7]$.

Table 1. Comparative analysis of ecological management and ecological control.

\begin{tabular}{|c|c|}
\hline $\begin{array}{l}\text { Ecological control } \\
\end{array}$ & $\begin{array}{c}\text { Ecological management } \\
\end{array}$ \\
\hline $\begin{array}{l}\text { Mandatory activities, determined by legal } \\
\text { requirements. }\end{array}$ & $\begin{array}{l}\text { Proactive and voluntary activities, } \\
\text { complementary to the requirements of the } \\
\text { legislation. }\end{array}$ \\
\hline $\begin{array}{l}\text { It is carried out by State authorities and by } \\
\text { economic entities as well }\end{array}$ & $\begin{array}{l}\text { Proactive and voluntary activities are } \\
\text { complementary to the requirements of the } \\
\text { legislation. }\end{array}$ \\
\hline $\begin{array}{l}\text { There is the lack of clearly defined and } \\
\text { documented environmental policies, goals } \\
\text { and targets. }\end{array}$ & $\begin{array}{l}\text { Environmental policies, goals and objectives are } \\
\text { clearly defined and documented. }\end{array}$ \\
\hline $\begin{array}{l}\text { There is the lack of goals associated with } \\
\text { consistent improvements. }\end{array}$ & The goals are aimed at consistent improvements. \\
\hline $\begin{array}{l}\text { It is carried out by responsible specialists, } \\
\text { without personnel involvement. }\end{array}$ & $\begin{array}{l}\text { It is carried out with the active participation of } \\
\text { the management of the enterprise and the } \\
\text { personnel. }\end{array}$ \\
\hline $\begin{array}{l}\text { Activities carried out within the framework of } \\
\text { job duties and instructions. }\end{array}$ & $\begin{array}{l}\text { Activities that depend on the manager 's personal } \\
\text { interest in the end results are defined by the } \\
\text { qualification of the manager. }\end{array}$ \\
\hline $\begin{array}{l}\text { The organization of activities does not change } \\
\text { or improve in time. }\end{array}$ & $\begin{array}{l}\text { The organization of activities is constantly } \\
\text { changing and improving in time. }\end{array}$ \\
\hline $\begin{array}{l}\text { Dominance of the management process over } \\
\text { the result. }\end{array}$ & $\begin{array}{l}\text { The prevalence of results over the management } \\
\text { process. }\end{array}$ \\
\hline Ignoring of negative results. & $\begin{array}{l}\text { Negative results become the foundation of } \\
\text { success }\end{array}$ \\
\hline $\begin{array}{l}\text { The absence of external independent } \\
\text { estimation }\end{array}$ & Periodic environmental audit \\
\hline
\end{tabular}

As one can be see, the enterprises implementing the environmental management system are interested in implementing environmental programmes, projects for safe production management, new technologies, treatment facilities to increase the effective use of resources and preserve the quality of the environment, while improving the efficiency of economic indicators $[8,9]$.

Today, after Russia's accession to the WTO, Russian enterprises in the market are beginning to experience competition from foreign enterprises, our producers have to think about how to strengthen their position in the market. One factor is a careful attitude towards environmental quality. Most European countries have long thought about the quality of the 
environment, which is the factor that depends on the life expectancy of the people of these countries $[3,5]$.

In Russia there are many enterprises which have implemented a system of environmental management, mainly enterprises of the metallurgical industry.

The reasons for the implementation of environmental management in the listed enterprises are the requirements of the external environment, for example, the mandatory presence of a certificate of compliance with the standard of environmental management for work in foreign markets. If this certificate is absent, then the goods cannot be let to the market or sell it at the lowered price (dumping of the prices) [10].

According to the authors, the development and issuance of international standards defining requirements to the environmental management system have opened a new stage in the globalization of the economy. The ISO 14000 series of voluntary standards have become a new tool for the competition in the international market. Thus, the introduction of an environmental management system at the Russian enterprises is an indicator of the choice of strategies for long-term business development and equal partnership with enterprises of developed countries of the world.

Based on the research carried out, it can be stated that today at the Russia enterprises apply environmental management, not an environmental management system. The environmental management system differs from environmental management, primarily by voluntary rather than legislative nature. The introduction of this system is due to the demand of the world market, the main prerequisites of which are the tightening of requirements for goods by foreign consumers caused by the processes of globalization.

\section{Methods}

The theoretical and methodological basis of the study was the works of domestic and foreign scientists, specialists in the field of natural environment protection, sustainable development, environmental management economy, environmental management system, assessment of economic efficiency of the enterprise. The study used methods of grouping comparative analysis, correlation-regression analysis, partial (sample) sociological research, etc.

The study was based on the legislative and regulatory documents, statistics, monographs and publications, materials of Russian and international scientific and practical conferences, results of studies conducted by the author.

\section{Results and Discussion}

\subsection{Analysis of the existing methods of environmental-and-economic efficiency assessment}

Many specialists interpret the concept of "environmental management" differently. Different interpretations influence the lack of understanding of the nature of environmental management in specialists in the enterprise who are engaged in the implementation of this system, in managers of enterprises who cannot accurately determine the effect of the implementation.

Many authors not only interpret the concept of environmental management differently, but also consider the effect of implementing environmental management one-sided, mainly by methods of calculating the effect of environmental management, although environmental management is wider than environmental management.

Traditionally, three main effects of environmental protection are identified: 
- social effect,

- ecological effect;

- economic effect.

Some authors in the field of environmental management and environmental economics combine all the effects, so it is quite difficult to make a clear classification of the calculation methods.

Figure 1 presents all the techniques, divided into statistical and dynamic methods for calculating effect and efficiency. Statistical methods allow to make calculations for a certain period (for example, for a year), dynamic methods take into account the factor of time. Some methods take into account both economic and environmental components, and some consider only economic or environmental components.

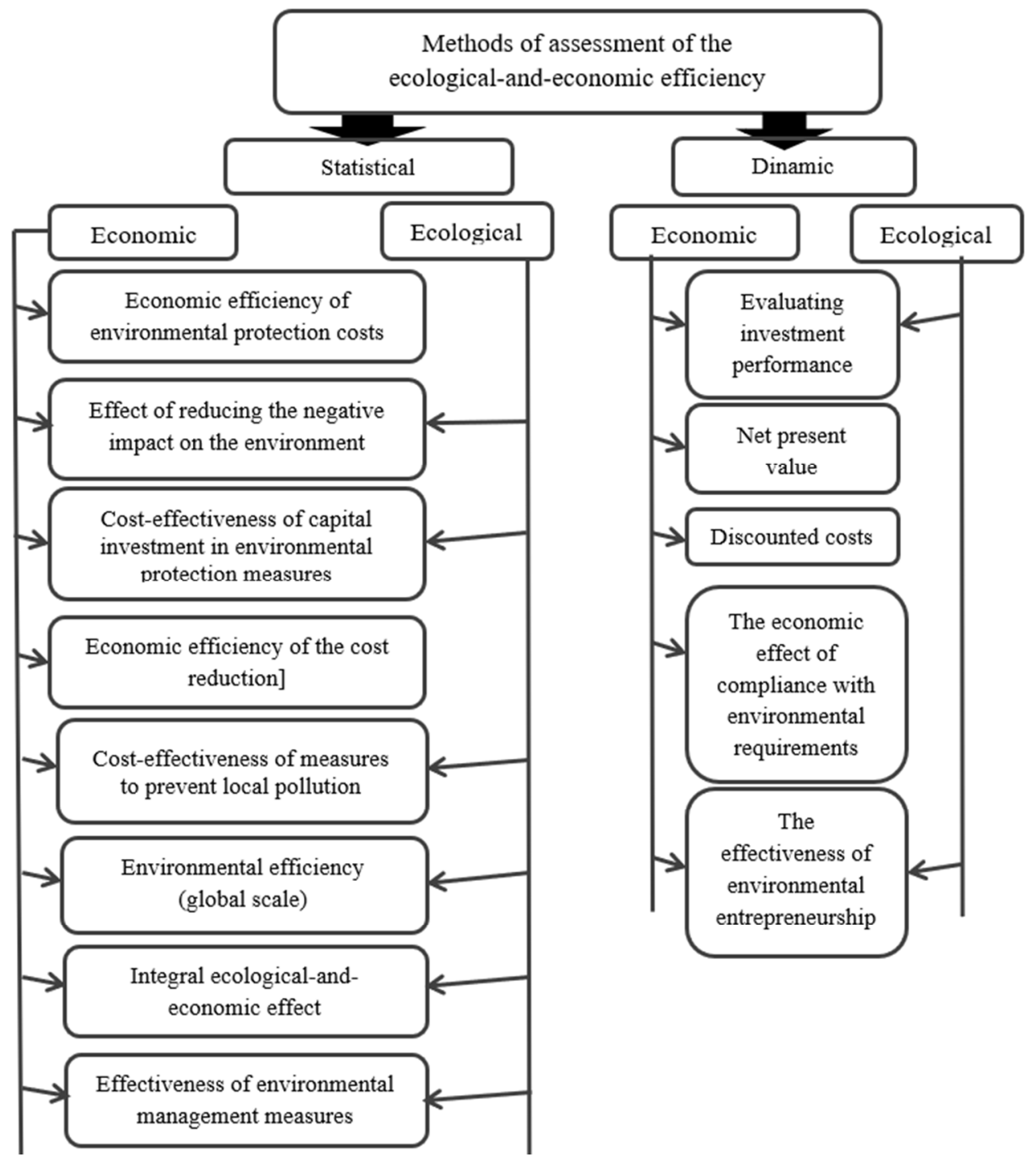

Fig. 1. Classification of methods of environmental-economic impact and efficiency assessment.

All the considered methods are devoted to the effectiveness of measures to reduce pollution of the natural environment, rather than to the functioning of the environmental 
management system at the enterprise. This system contributes to increasing the performance of the enterprise, such as revenue, profit, solvency, competitiveness, etc.

We do not discuss the importance of the methods proposed by environmental management specialists, but we believe that they do not reflect the economic interest of enterprises in the implementation of the environmental management system.

As a result, we noted that the damage prevented was only related to the environment, but the cost of preventing it was borne by the enterprise.

As one be see from the analysis, all actions from the application of environmental protection equipment, environmental protection programs, resource saving programs, etc., are aimed at reducing damage to the environment. All enterprises are aimed at profit generation and quick return on capital investments. Therefore, there was a need to develop a methodology that would show these advantages.

\subsection{Methodological approach to calculation of economic efficiency of implementation and functioning of environmental management system}

Traditionally, three effects are identified within the calculation of the effectiveness of environmental measures: social, environmental and economic. For the management of an industrial enterprise, the economic effect is the most significant. It should be borne in mind that the introduction of environmental measures rarely leads to a reduction in the cost of products, the most likely result is the growth of revenues due to the growth of sales volumes and the price of environmentally friendly products.

Environmental management allows the enterprises to obtain some opportunities for further effective activities. Those include environmental improvements; establishing contacts with environmental services, with the public; increased Russian market share; improving the image of the enterprise, etc. Thus, it can be concluded that the functioning of the environmental management system is wider than the ISO 14001 compliance certificate.

The authors analyzed the existing methods of the environmental-economic efficiency assessment. The analysis proved that despite various names ("economic efficiency of environmental protection costs," economic efficiency of environmental measures, "efficiency of environmental entrepreneurship," etc.), the main components of the effect include: reduction of payments for pollution of the natural environment, reduction of penalties, prevented environmental damage, reduction of cost due to more rational use of resources, etc. From the analyzed sample only a few methods take into account the revenue growth, and the increase of production volumes.

None of the methods takes into account the growth of economic results due to the increase in the image of the enterprise.

The results from the implementation of the environmental management system based on the method of calculating the economic effect in the implementation and operation of the environmental management system, taking into account the image component, are presented in Figure 2. The image component of the economic effect allows to take into account the growth of revenues due to the increase in price and production volumes while increasing loyalty of the consumers. 


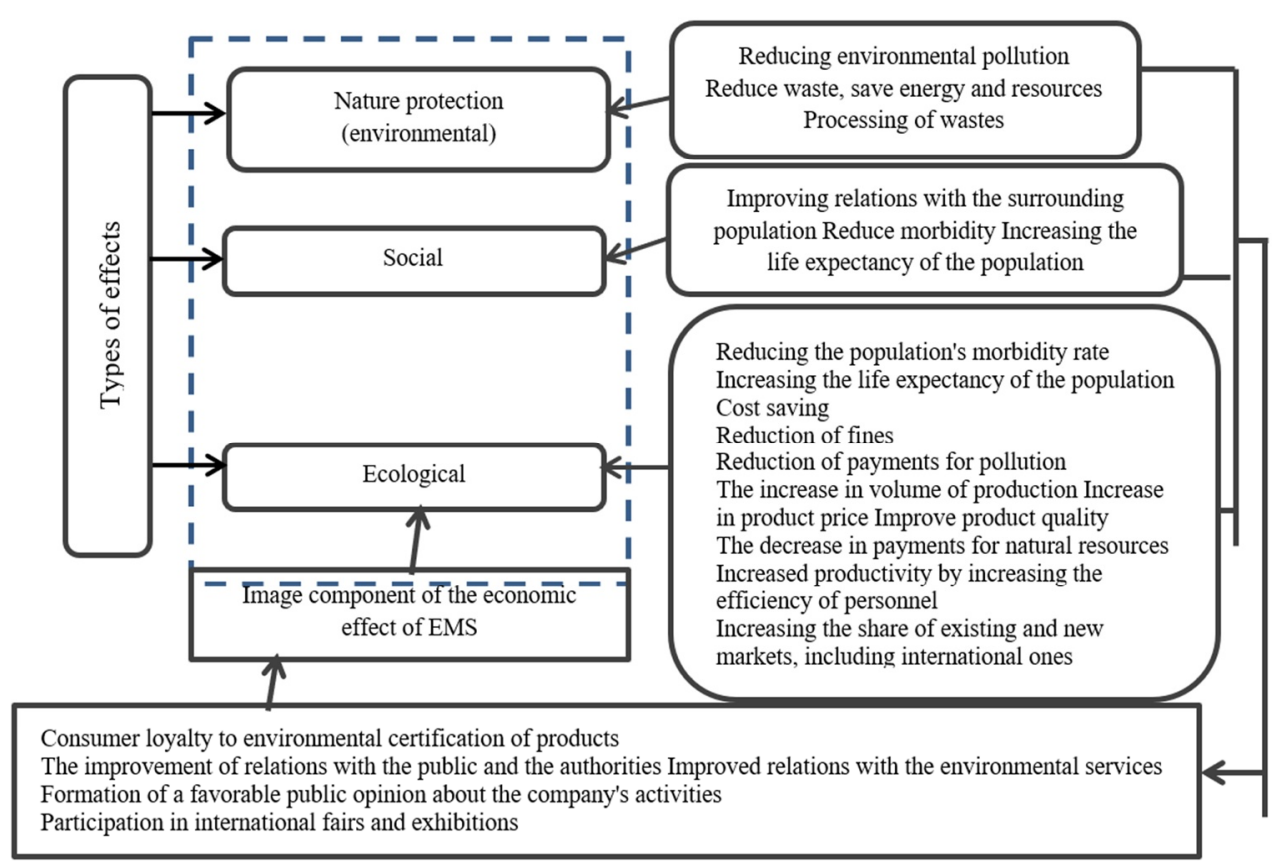

Fig. 2. Results from the implementation of the environmental management system.

\subsection{Assessment of the impact of the implementation of the environmental management system on the economic results of the industrial enterprises}

Despite all the positive advantages of implementing an environmental management system, Russian enterprises do not seek to implement this system. This is clearly seen in Figure 3. China, Japan, is the most active country in this regard. Then there are the countries of Europe. Russia takes almost the last place. [208]. In our country, enterprises that need to sell their products on the international market are mainly implementing this system, the rest do not see any point in it. 12].

In Russia, not all the enterprises introduce an environmental management system [11,

The lack of interest of Russian enterprises to introduce an environmental management system is due to the fact that the management of enterprises does not see the economic benefit of this system [13].

Nowadays in Russia, administrative methods are applied to enterprises that do not help to reduce pollution of the natural environment. In our opinion, it is necessary to apply economic methods that most fully assess the economic efficiency of the implementation and operation of EMS for the management of enterprises.

In Russia, the process of implementing the environmental management system began approximately in 2000. The first to introduce this system were enterprises of mining, processing and metallurgical industry. (For example, GAZPROM Joint Stock Company, Joint Stock Company Oil Company LUKOIL, Joint Stock Company Lipetskiy Metallurgical Plant, Joint Stock Company Pipe Metallurgical Company, etc.). Since about 2005, enterprises of chemical and machine-building industry have joined this process, namely JSC "MMK" Norilsk Nickel, "JSC" Silvinit, "etc. In the Sverdlovsk region, the enterprise of Joint Stock Company "Nizhnetagil Metallurgical Plant" became a pioneer for 
the implementation of the environmental management system. In the future, enterprises of UGMK Holding, enterprises of machine-building industry, etc., joined this list.

Enterprises of the machine-building industry have mainly started to introduce economy management since 2007. This is because, firstly, they are the only suppliers of products that are often unique, so a ISO 14001 compliance certificate is not required. Second, the products of enterprises in this industry enter markets where a certificate is not needed.

Since the early 2000ths, the products entering the international market must be accompanied by a certificate of conformity with ISO 14001 .

Due to these requirements, the introduction of eco-management in enterprises in these industries has become necessary.

The main result of the implementation of environmental management should be the growth of sales volumes (including for export) both due to the quantitative, price and image components of the economic effect.

Russia is currently implementing international environmental programmes and adopting conventions on environmental protection; The era of ecologization of the economy has begun. There are many industrial enterprises in Russia that have a negative impact on the environment. To reduce this impact, enterprises need to follow a green course.

Enterprises operating an environmental management system must periodically carry out an environmental audit, by means of which it is determined whether the system meets the requirements of the International Standard ISO 14001 series and for how much its operation is maintained and maintained. Types of environmental audit [14] are presented in Figure 3.

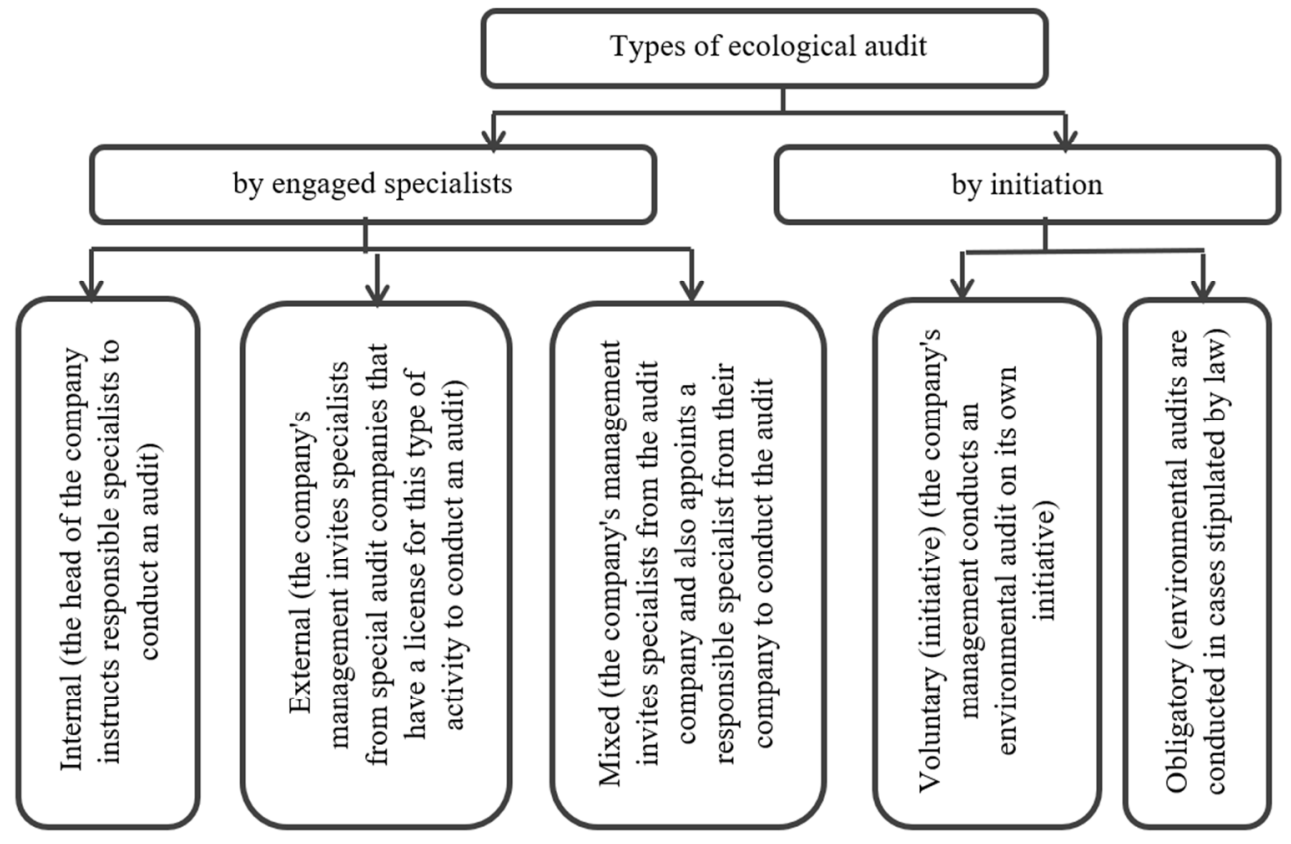

Fig. 3. Types of environmental audit.

After the environmental audit, a quantitative and qualitative assessment of the effectiveness of implementation at environmental management enterprises is carried out. Quantitative evaluation is carried out on the basis of a system of various indicators that allow to assess the efficiency of environmental management and management. Qualitative assessment is an environmental assessment of enterprises, in which the achieved results of voluntary environmental activity of enterprises in the field of environmental management are assessed [6]. 
Today, enterprises that need access to the international market conduct international verification and obtain ISO 14000 certification, thus ensuring not only market entry, but also increasing their competitiveness. International companies such as DQS (Germany), TUF (Germany) and Veritas (France) are currently conducting this review.

During the environmental audit, natural resources, quality of atmospheric air and water bodies, soil resources, noise, vibration, electromagnetic pollution, as well as the possibility of emergency situations at the enterprises of the city are assessed. The audit should be followed by a report and recommendations for the future [14, 15].

Standardization and environmental audit attract the attention of international organizations to the enterprise and provide additional opportunities for the development of relations with business partners abroad, create trust relations with investors, local authorities and state environmental control bodies, the population, strengthen and expand the position of enterprises in international and financial markets.

Voluntary environmental audit at international enterprises is carried out to identify not only positive but also negative results of the implementation of the environmental management system. At the same time, the negative result is not silent, but is actively advertised on the official website, mass media and all measures are taken to eliminate these results.

The classic model of the environmental management system discussed in ISO 14001 is shown in Figure 4.

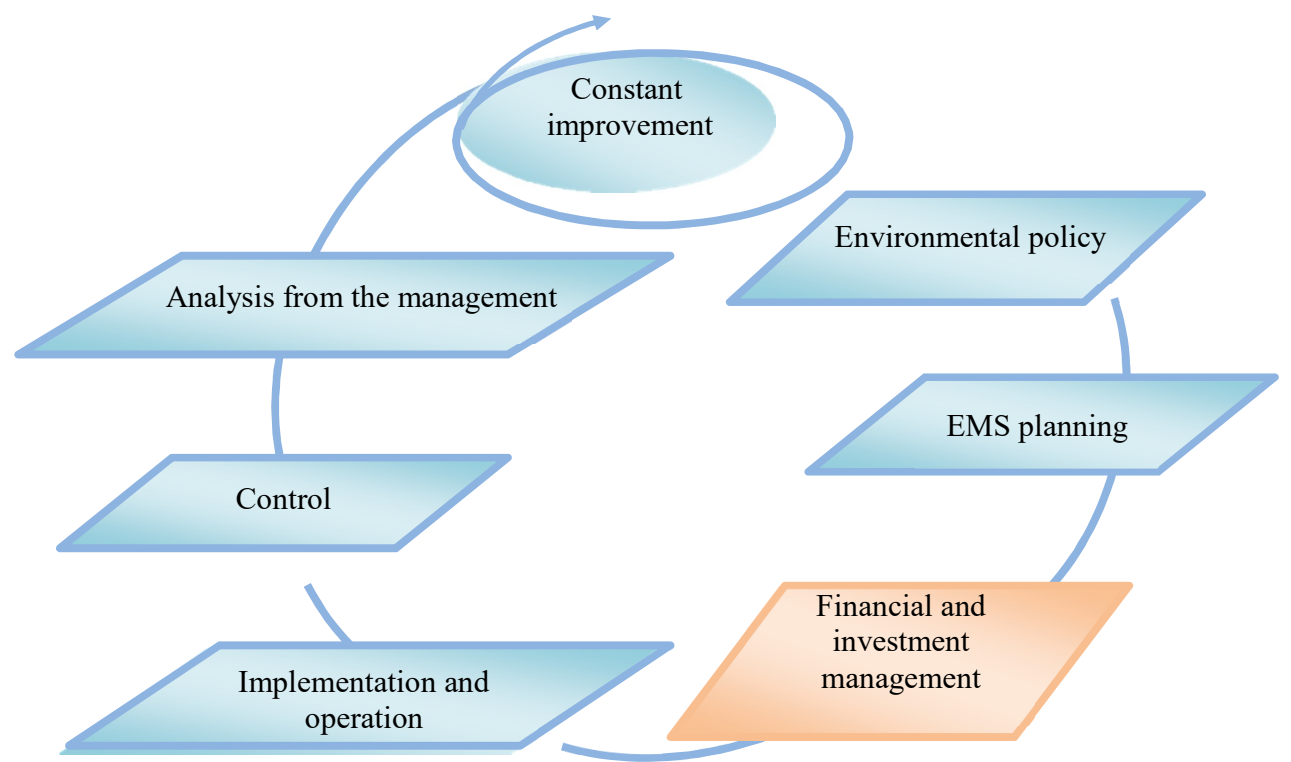

Fig. 4. Proposed model of the environmental management implementation and validation system.

The model shows a process involving a continuous planning process, maintenance, evaluation of the SEM process (through monitoring), situation analysis and follow-up actions that will improve environmental performance.

The study assessed methodological approaches to determining the economic impact of the implementation and functioning of the environmental management system. It can be said that none of the existing methods shows comprehensive results for the management of the enterprise from the implementation of the environmental management system.

It is notionally possible to divide all techniques into two groups. The first group includes statistical methods. In turn, it is divided into methods that take into account the 
economic result from prevented environmental damage and methods of environmentaleconomic efficiency. The second group is dynamic methods.

Most of the methods for calculating economic effect and economic efficiency are based on a temporary standard methodology for determining the economic efficiency of environmental measures and assessing economic damage, a number of authors take into account revenue growth, including through price, increase in production volumes.

We do not dispute the importance of the methods $[16,17,18,19,20]$, proposed by experts in the field of nature management, but we believe that none of the methods takes into account the increase in economic results due to the increase in the image of the enterprise.

\section{Conclusion}

1. The study proved the author 's hypothesis on the existence of an image component of the economic effect in the implementation of the ecological management system at the enterprise and the receipt of an ecological certificate.

2. The prerequisites for the implementation of environmental management are considered.

3. Three main types of effects were analyzed: social, economic, environmental.

4. In accordance with the classification of methods for the assessment of ecologicaleconomic effect and efficiency, a methodological approach was proposed for the calculation of economic effect in the implementation and functioning of the ecological management system, taking into account the image component of the economic effect.

5. The introduction of the environmental management system, improving the image of the enterprise, will have a favorable impact on the competitiveness and business reputation of the enterprise.

\section{References}

1. L.M. Albiter, The Journal of SamGTU. Series Economic sciences 4(10), 141-143 (2013)

2. Yu.V. Babina, Problems of Regional Ecology 4, 103-112 (2004)

3. Boiral O., Journal of Environmental Management 99, 84-97 (2012)

4. M. Casadesus, Journal of Cleaner Production 16, 1741-1754 (2008)

5. P.F. Drucker, Tasks of Management in the XXI Century (Williams Publishing House, Moscow, 2004)

6. L.M. Maslennikov, V.N. Kuznetsov, Environmental Management: Tutorial (SPbGIEU, Saint-Petersburg, 2005)

7. N.V. Pakhomova, Economics of Nature Management and Environmental Protection (University of St. Petersburg, Saint-Petersburg, 2000)

8. N.V. Dukmasova, Collection of Scientific Works of the Fifth All-Russian Scientific and Practical Conference with International Participation (GOU VPO UGTU-UPI, Yekaterinburg, 2006)

9. A. Mottaeva, J. Ćetković Advances in Intelligent Systems and Computing, 692, 11511159 (2018) doi: 10.1007/978-3-319-70987-1_123

10. N.V. Dukmasova, UrFU Gazette. Economics and Management Series UrFU 6, 90-97 (2013)

11. S.Y. Dayman, Environmental Management Systems for Practitioners (RSTU, Moscow, 2004) 
12. N.V. Mamon, Management in Russia and abroad 2, 80-91 (2010)

13. O.A. Prusuzhalov, Ecology of production. Scientific and practical magazine 5, 26-30 (2009)

14. E. Vasilyeva, A. Mottaeva, E3S Web of Conferences 91, 08051 (2019)

15. M.E. Chepelkin, Ecology of production. Scientific and practical magazine 7, 33-37 (2010)

16. A.D. Vesharets, Economics of Nature Management (Economics and Informatics, Moscow, 1994)

17. Yu.N. Zhuchenko, Russian entrepreneurship 9(2-167), 32-37 (2010)

18. E.R. Magaryl, Economics and Governance 5, 114 - 130 (2013)

19. N.V. Pakhomova, Economics and ecology 1(37) (2011)

20. M.N. Saldayeva, SamGTU Gazette. Series Economic sciences 3(9), 148-155 (2013)

21. Y. Yandyganov, Economics of the region, 143-153 (2008) 